\title{
Palatability of the Asian clam Corbicula fluminea (Müller 1774) in an invaded system
}

\author{
P. S. Castro $\cdot$ M. I. Ilarri ${ }^{\circ} \cdot$ V. Modesto $\cdot$ C. Antunes $\cdot$ R. Sousa
}

Received: 1 October 2016/Revised: 3 February 2017/Accepted: 20 February 2017/Published online: 6 March 2017

(C) Springer International Publishing Switzerland 2017

\begin{abstract}
Biotic interactions such as predation may influence the success of invasive alien species (IAS). Although the Asian clam Corbicula fluminea is recognized as one of the most problematic aquatic IAS, few studies have investigated its use as a food resource. In this study, we aimed to investigate (i) the palatability of C. fluminea under natural (Minho River) and laboratory conditions and (ii) if $C$. fluminea submitted to different conditions (individuals from Lima and Minho Rivers) vary in palatability. Soft tissues from different Corbicula populations, plus soft tissues from a native clam, tuna and Corbicula shell powder were offered to consumers. Field assays were performed seasonally and laboratory assays only in summer; both assays also
\end{abstract}

Guest editors: Manuel P. M. Lopes-Lima, Ronaldo G. Sousa, Lyuba E. Burlakova, Alexander Y. Karatayev \& Knut Mehler / Ecology and Conservation of Freshwater Bivalves

P. S. Castro and M. I. Ilarri made equal contributions to this work.

P. S. Castro - V. Modesto - R. Sousa

Department of Biology, CBMA - Centre of Molecular and Environmental Biology, University of Minho, Campus de Gualtar, 4710-057 Braga, Portugal

M. I. Ilarri $(\varangle) \cdot$ V. Modesto · C. Antunes · R. Sousa CIIMAR/CIMAR - Interdisciplinary Centre of Marine and Environmental Research, University of Porto, Terminal de Cruzeiros do Porto de Leixões, Av. General Norton de Matos s/n, 4450-208 Matosinhos, Portugal

e-mail: martinailarri@gmail.com tested possible differences during distinct periods of the day. Overall, in natural conditions, the treatments containing $C$. fluminea had a low palatability. In laboratory assays, higher consumption (almost two times) was observed for Cyprinus carpio and Anguilla anguilla. Also, C. fluminea palatability was different between populations, with the treatment Corbicula Lima being more consumed than Corbicula Minho. Despite the low values of consumption in the field, laboratory results suggest that $C$. fluminea soft tissues can be a food resource to some species.

Keywords IAS · Invasion · Biotic resistance · Predation $\cdot$ Aquatic ecosystem

\section{Introduction}

Invasive alien species (IAS) have been dispersing worldwide at unprecedented rates in the last decades

\footnotetext{
M. I. Ilarri

ICBAS-UP - Abel Salazar Biomedical Science Institute, University of Porto, Rua de Jorge Viterbo Ferreira, 228, 4050-313 Porto, Portugal

C. Antunes

Aquamuseu do Rio Minho, Parque do Castelinho s/n, Vila Nova de Cerveira, 4920-290 Porto, Portugal
} 
(Simberloff et al., 2013), causing serious changes in biodiversity, both in terrestrial and aquatic ecosystems (Ehrenfeld, 2010; Vilà et al., 2010; Strayer, 2012). These species can change native communities through biological processes such as predation, introduction of parasites, diseases, competition for available resources, and altering abiotic conditions and ecosystem functioning (Sousa et al., 2011a; Gutiérrez et al., 2014).

Although the number of studies concerning biological invasions increased in the last decades, most studies focused on the impacts of IAS on native species, rather than on native communities influencing the possible establishment and impact of IAS (Carlsson et al., 2011). Indeed, the success and spread of an IAS in a recipient ecosystem can be related to the interaction of several factors (Ford, 1996; Lonsdale, 1999). A relevant biotic factor influencing the success of a given IAS is the lack of enemies (e.g., competitors, parasites, diseases), including predators (Keane \& Crawley, 2002; Colautti et al., 2004). Predators can control IAS populations due to their ability to switch from their earlier preferred food in response to the new prey availability (Carlsson et al., 2011). In fact, a recent meta-analysis showed that biotic resistance provided by local predators can limit invasions, and suggested that predators can be especially effective in constraining IAS in aquatic ecosystems (Alofs \& Jackson, 2014). For example, the blue crab [Callinectes sapidus (Rathbun, 1896)] in the Hudson River (USA) increased mortality of zebra mussels [Dreissena polymorpha (Pallas, 1771)] and changed the population structure of this IAS (Carlsson et al., 2011). Also, Dorn \& Hafsadi (2016) observed that the native crayfish ([Procambarus fallax (Hagen, 1870)] contributed to an eightfold increase predation on the eggs of the invasive apple snail Pomacea maculata (Perry, 1810) in comparison to the native apple snail P. paludosa (Say, 1829). Nevertheless, it is difficult to predict the temporal scale determining this biotic resistance (it can range from a lifetime of the individual to several generations), besides it is also dependent on the environmental conditions of the invaded system (Carlsson et al., 2011).

The Asian clam Corbicula fluminea (Müller, 1774) is recognized as one of the most problematic IAS in aquatic ecosystems due to its widespread distribution and high density reached in many invaded ecosystems (Sousa et al., 2008d; Crespo et al., 2015). However, in some ecosystems, this IAS has a restricted spatial distribution and attained a very low density (Sousa et al., 2006). Possible explanations for these discrepancies in the invasive pattern may include different propagule pressure, different abiotic conditions and disturbance regimes, and distinct biotic resistance between invaded ecosystems (Sousa et al., 2008d). Therefore, the study of the possible factors responsible for these different invasive patterns may be relevant from an ecological and management point of view, being the biotic resistance mediated by predators in the recipient ecosystem a possible key factor that should be evaluated (Alofs \& Jackson, 2014). Bivalves are well protected by their shells that in several cases can act as an anti-predation physical defense. In the particular case of $C$. fluminea, this clam presents harder shells compared to other native bivalves (Ilarri et al., 2015a). Despite their hard shells that may contribute to low predation rates, nothing is known about their soft tissues as a food resource to possible consumers. Specifically, the present study aimed to investigate (i) the palatability of $C$. fluminea under natural (Minho River) and laboratory conditions and (ii) if $C$. fluminea submitted to different conditions (individuals from Lima and Minho Rivers) vary in palatability.

\section{Materials and methods}

Field study area

The field experiment was conducted near Praia da Lenta $\left(41^{\circ} 57^{\prime} \mathrm{N}, 8^{\circ} 44^{\prime} \mathrm{W}\right)$, a semi-enclosed area located $14 \mathrm{~km}$ upstream the mouth of the Minho River (NW of the Iberian Peninsula). This river has $310 \mathrm{~km}$ in total length and flows NNE-SSW into the Atlantic Ocean, being its headwaters located in Serra de Meira, province of Lugo, Spain. Its last $70 \mathrm{~km}$ comprise the natural border between Portugal and Spain and it has a maximum width of $2 \mathrm{~km}$ near the mouth. The Minho River basin has a total area of about $17,080 \mathrm{~km}^{2}$, being $95 \%$ located in Spain and $5 \%$ in Portugal. The influence of spring tides is nearly $40 \mathrm{~km}$ and the water in the Minho River estuary is partially mixed, with the exception of when high floods occur in which it tends to salt wedge conditions (Sousa et al., 2005, 2008a).

Corbicula fluminea was first reported in Minho estuary in 1989 (Araujo et al., 1993). Currently, the 
species contributes with more than $90 \%$ of the benthic estuarine biomass (Sousa et al., 2008b). Although there are many studies addressing the general ecology and main impacts on ecosystem functioning generated by this IAS in the Minho River (e.g., Sousa et al., 2008a, 2011b; Ilarri et al., 2011, 2015a, b; Novais et al., 2015a, b, 2016a, b), so far, any addressed the possible importance of predation facilitating their invasive success. The density of $C$. fluminea at Praia da Lenta is high (Sousa et al., 2008c), and the biotic and abiotic conditions of this semi-enclosed area are well known (Sousa et al., 2013; Mota et al., 2014). In summary, the study area comprises sandy and muddy habitats heavily covered by submerged vegetation (mainly by the IAS Egeria densa (Planch)). Abiotic data collected in recent studies (e.g., Sousa et al., 2013; Mota et al., 2014) showed high annual variability in temperature (minimum and maximum all over the year: $\left.8.5-25^{\circ} \mathrm{C}\right)$, conductivity $\left(0.1-0.6 \mathrm{mS} \mathrm{cm}{ }^{-1}\right)$, dissolved oxygen $\left(7.5-11.8 \mathrm{mg} \mathrm{l}^{-1}\right)$, redox potential $(65.5-189.3 \mathrm{mV})$ and $\mathrm{pH}(7.0-8.0)$, as expected for a temperate aquatic ecosystem. In the last 8 years, fyke nets have been deployed in the area to characterize the fish and crustacean fauna (for details, see Sousa et al., 2013; Mota et al., 2014).

\section{Field assays}

Palatability was tested using food pellets prepared in a matrix of carrageenan. This matrix was made mixing $3.5 \mathrm{~g}$ of carrageenan with $60 \mathrm{ml}$ of distilled water and $25 \mathrm{ml}$ of a semi-liquid mass of the respective mashed treatment (i.e., native clam, crude tuna, shell powder + crude tuna, $C$. fluminea soft tissues collected in the Minho and Lima Rivers; see below for details about treatments) following Pawlik \& Fenical (1992). The mixture was then heated to boiling in a microwave with full power for approximately one minute. The melted mixture was poured into a mold with cotton strings crossing it. After the matrix was cooled, it was cut in ten equally sized $(5 \times 1 \times 1 \mathrm{~cm})$ strips with a scalpel, resulting in a cotton string attached to each strip.

In the experiment, five treatments were used:

(1) prepared with the common cockle [Cerastoderma edule (Linnaeus, 1758)], a common species in Portuguese estuaries, this treatment was used as control of $C$. fluminea (hereafter, Clam treatment);

(2) prepared with crude Tuna (hereafter, Tuna treatment), this treatment was used as a feeding stimulant in order to see if consumers responded to the available food pellets;

(3) prepared with C. fluminea shells powder and crude tuna, this treatment aimed to mimic the role of $C$. fluminea shells hardness as a physical anti-predation defense (hereafter, Shell powder). The inclusion of this treatment allows us to separate the effect of $C$. fluminea shells from their soft tissues, and have a better idea regarding what could be attractive and avoided by the possible predators. In this treatment, we defined the amount of shell powdered based on the shell weight to soft body weight ratio of the species. The Mixer Mill MM 200 Retsch was used to crush the shells in powder;

(4) prepared with C. fluminea soft tissues collected in the Minho River (hereafter, Corbicula Minho);

(5) prepared with C. fluminea soft tissues collected in the Lima River (hereafter, Corbicula Lima).

In order to avoid bias, only adults of $C$. fluminea (>25 mm) were used. Treatments containing $C$. fluminea soft tissues (i.e., Corbicula Minho and Corbicula Lima) were used to test if the species palatability varies when submitted to different environmental conditions. Both systems are colonized by C. fluminea; however, in the Lima River, the Asian clam has a very low density, its distribution is restricted to a very small area, and available data suggest that predation (among other factors) may contribute to the lower density present in this river (Sousa et al., 2006). Conversely, previous studies suggest that predation is very low in the Minho River (Ilarri et al., 2014).

In each field assay, ten replicates of each treatment (Clam, Tuna, Shell powder, Corbicula Minho and Corbicula Lima) were used. A string of $10 \mathrm{~m}$ in length, divided in ten segments ( $1 \mathrm{~m}$ each), was used to attach the replicates. In each meter, the five different treatments were tied equally spaced and organized following always the same order (Clam, Tuna, Shell powder, Corbicula Minho, and Corbicula Lima). The string was placed above the bottom during two hours 
(adapted from Pawlik \& Fenical, 1992; Epifanio et al., 1999) and consumption was recorded as percentage of food pellet eaten.

In order to assess if the consumption was influenced by seasonal variations, the experiment was conducted twice in all seasons during one year $(n=20$ replicates per season). In addition, to investigate possible daily differences, assays were performed during the day and night time. Furthermore, to avoid possible bias introduced by tidal influences, assays were always carried out during high-tide conditions.

\section{Laboratory assays}

Laboratory assays were performed to access in a more controlled way the palatability of $C$. fluminea to potential main consumers that inhabit the study area (i.e., Praia da Lenta). For this, the native species Anguilla anguilla (Linnaeus, 1758) and three IAS, Cyprinus carpio (Linnaeus, 1758), Lepomis gibbosus (Linnaeus, 1758), and Procambarus clarkii (Girard, 1852) were selected. All the four species were chosen either because of reports in the literature confirming their ability to consume $C$. fluminea in other invaded systems (French, 1993; Molloy et al., 1997), and/or due to the fact that they have feeding traits considered efficient to prey on bivalve species (Tucker et al., 1996; Molloy et al., 1997; Ilhéu et al., 2007; Bouchereau et al., 2009). Furthermore, the four species are among the most abundant in the studied area and had been in contact with $C$. fluminea before (Sousa et al., 2013, Mota et al., 2014).

After collection in June 2015, in Praia da Lenta (Minho River), individuals were transported to the University of Porto (CIIMAR) and kept in tanks under constant aeration, at approximately $23^{\circ} \mathrm{C}$, which was similar to the temperature reached in the studied area during summer (Mota et al., 2014). The total length of the individuals used ranged from 23 to $40 \mathrm{~cm}$ for $A$. anguilla, 8 to $12 \mathrm{~cm}$ for $C$. carpio, 8 to $12 \mathrm{~cm}$ for $L$. gibbosus, and 9 to $11 \mathrm{~cm}$ for $P$. clarkii. Prior to the assays, the individuals were kept in the tanks for two weeks (acclimation period) and fed with frozen mussels every 3 days. After acclimation, we considered keeping the individuals under starvation for a 6-day period.

The experimental design for the assays included one predator per tank (dimensions of $23.3 \times 27 \times 30 \mathrm{~cm}$ ) filled with 15.01 of fresh water at the same temperature as in the containers. We used opaque glasses on the tanks to avoid any disturbance on fish and crayfish during the assays. Before each assay, the individuals were acclimatized in the tank for three days, subject to $12: 12 \mathrm{~h}$ of a light-dark cycle. Each individual was exposed simultaneously to the five different treatments during two hours. The same methodology, as described above (field assays), was used to prepare the food pellets. Six individuals per species ( $n=6$; one per tank) were used in the assays. The experimental design was the same used in the field assays; and the food pellets were also placed above the bottom for two hours. Consumption was recorded as percentage of food pellet eaten. Differences in consumption between the periods of the day (i.e., day, with high intensity light, and night, with full dark conditions) were also assessed.

Both field and laboratory assays were conducted in agreement with the guidelines on the protection of animals used for scientific purposes according to the European Union directives (2010/63/UE).

\section{Data analysis}

To assess possible differences in consumption, Permutational Multivariate Analysis of Variance (PERMANOVA) was used. This method analyzes the variance of multivariate data explained by a set of explanatory factors, on the basis of any chosen measure of distance or dissimilarity, thereby allowing for a wide range of empirical data distributions (Anderson, 2001). Before conducting statistical tests, all variables were always normalized and a resemble matrix based on the Euclidean distances was calculated. For the field assays, the overall consumption of food pellets was statistically tested with a three-way PERMANOVA (type III), with treatments (five levels: Clam, Tuna, Shell powder, Corbicula Minho, and Corbicula Lima), season (four levels: Autumn, Winter, Spring, and Summer), and day period (two levels: Day and Night) as fixed factors. For the laboratory assays, a two-way PERMANOVA (type III) was also performed to test the overall consumption of food pellets in each treatment by the selected species, during the day and night time. For these PERMANOVA tests, treatments (five levels: Clam, Tuna, Shell powder, Corbicula Minho, and Corbicula Lima) and day period (two levels: Day and Night) were used as fixed factors. 
In all PERMANOVA tests, the statistical significance of variance $(\alpha=0.05)$ was tested using 9999 permutations of residuals within a reduced model. Also, pairwise comparisons were performed in all the results with statistically significant differences, within PERMANOVA tests.

For all the statistical tests, we used PRIMER analytical software (vers. 6.1.6, PRIMER-E Ltd, Plymouth, U.K.) with PERMANOVA+ 1.0.1 add-on (Anderson et al., 2008).

\section{Results}

Field assays

The most consumed treatment was Tuna (average + standard deviation; $2.42 \% \pm 9.07$ ) followed by Corbicula Lima $(1.74 \% \pm 6.97)$, and the least consumed was Shell powder $(0.72 \% \pm 3.59)$ (Fig. 1).

Consumption in the field varied significantly through the treatments, season and day period (Table 1). Regarding treatments, the pairwise tests showed that most of the variation was associated to the lower values observed for Clam and Shell powder, compared to Tuna (Fig. 1). Also, regarding seasons, differences were mainly associated to the lower values during winter $(0.23 \%+0.72)$, when compared to the other seasons (autumn $=1.77 \% \pm 6.43$, spring $=$ $1.61 \%+6.07, \quad$ and $\quad$ summer $=1.96 \% \pm 7.41)$ (Fig. 2). Considering day period, the difference was associated to the higher consumption during the night $(2.19 \% \pm 7.37)$ compared to the day $(0.73 \% \pm 3.93)$ (Fig. 2).

\section{Laboratory assays}

The most consumed treatment was Tuna (average \pm standard deviation; $4.93 \% \pm 14.28$ ) followed by Corbicula Lima $(4.71 \% \pm 8.62)$, and the least consumed was Shell powder $(1.40 \% \pm 3.25)$ (Fig. 3).

P. clarkii $(6.15 \% \pm 13.80)$ was the species with the highest consumption during the assays (Fig. 4a). $P$. clarkii consumed mostly Tuna and less Clam. $C$. carpio $(3.78 \% \pm 7.39)$ was the second species with higher consumption; it mainly consumed Clam and less Shell powder (Fig. 4b). A. anguilla $(2.02 \% \pm 2.90)$ was the third species with higher consumption; it most consumed Corbicula Lima and less Shell powder (Fig. 4c). L. gibbosus $(1.72 \% \pm 2.11)$ was the species that had the lowest consumption during the assays, which consumed preferentially Clam and less Shell powder (Fig. 4d).

The species overall consumption varied significantly through the interaction of the treatments and day period (Table 2). The consumption of $C$. carpio and $A$. anguilla also varied through the interaction of the treatments and day period (Table 2). However, $L$. gibbosus varied significantly through the different treatments and day period (Table 2). P. clarkii consumption did not vary significantly through the different treatments and day period (Table 2). The

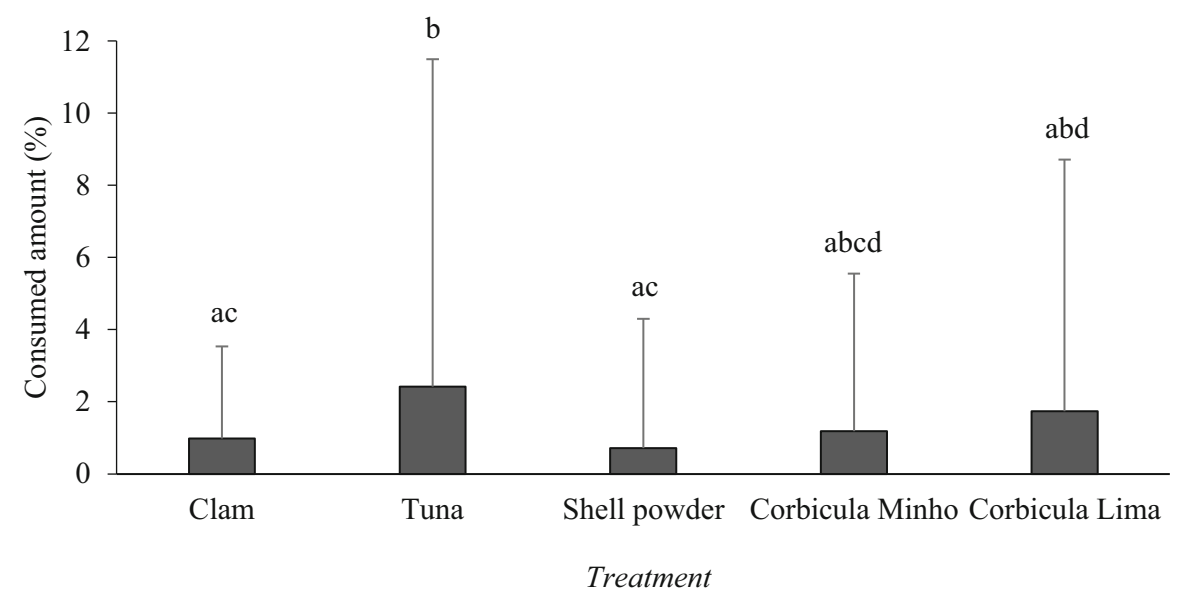

Fig. 1 Overall consumption of the five different treatments (Clam, Tuna, Shell powder, Corbicula Minho, and Corbicula Lima) in the field assays. Different letters indicate significant differences between them (three-way PERMANOVA pairwise tests; $P<0.05$ ) 
Table 1 Three-way PERMANOVA results, comparing the consumption of the treatments (Clam, Tuna, Shell powder, Corbicula Minho, Corbicula Lima) in the field assays among season (autumn, winter, spring, and summer) and day period (day and night)

\begin{tabular}{|c|c|c|c|c|c|}
\hline Source & df & SS & MS & Pseudo-F & $P$ \\
\hline Treatment & 4 & 10.11 & 2.53 & 2.61 & $<0.05$ \\
\hline Season & 3 & 11.14 & 3.71 & 3.84 & $<0.05$ \\
\hline Day period & 1 & 13.31 & 13.31 & 13.77 & $<0.01$ \\
\hline Treatment $\times$ season & 12 & 10.52 & 0.88 & 0.91 & ns \\
\hline Treatment $\times$ day period & 4 & 5.36 & 1.34 & 1.39 & ns \\
\hline Season $\times$ day period & 3 & 6.10 & 2.03 & 2.10 & ns \\
\hline Treatment $\times$ season $\times$ day period & 12 & 10.51 & 0.87613 & 0.91 & $\mathrm{~ns}$ \\
\hline
\end{tabular}

$n s$ non-significant $P$ value

pairwise tests showed that regarding the treatments most of the variation during the day was related to the lower consumption observed for Shell powder compared to other treatments, whereas during the night a preference for Corbicula Lima was observed. Also, regarding the day period, most of the differences were associated to a higher consumption during the day of the treatment Clam compared to the night, and a higher consumption of Corbicula Lima and Corbicula Minho during the night compared to the day.

\section{Discussion}

Results of the present study suggest that the treatments containing C. fluminea (i.e., Corbicula Minho and Corbicula Lima) had a low palatability. Low values of consumption were observed mainly in the field assays, with the highest values not exceeding $4 \%$ on average. In laboratory, some preference was observed regarding A. anguilla $(9.6 \% \pm 2.25)$ and C. carpio $(8.3 \% \pm 17.99)$, for the treatment Corbicula Lima during the night.

In the Minho River, there are some species capable to adapt to a molluscivory diet such as $A$. anguilla, C. carpio, L. gibbosus, and the crayfish $P$. clarkii. These species have morphological pre-adaptations that include strong jaws (i.e., A. anguilla; French, 1993; Molloy et al., 1997; Bouchereau et al., 2009), molariform pharyngeal teeth (i.e., C. carpio; Tucker et al., 1996), cardiform pharyngeal teeth (i.e., L. gibbosus; French, 1993; Molloy et al., 1997), and strong handling power (i.e., P. clarkii; Ibrahim et al., 1995; Ilhéu et al., 2007). Despite the presence of potential predators in the Minho River, results of the
Fig. 2 Seasonal consumption of the five different treatments (Clam, Tuna, Shell powder, Corbicula Minho, and Corbicula Lima) in the field assays performed in the Minho River, during the day ( gray color) and night (black color) periods. The overall food pellets' average consumption is represented by the dotted horizontal line

field assays suggest that $C$. fluminea is yet not attractive as a food resource. However, the higher values of consumption observed in the laboratory assays for $C$. carpio and A. anguilla indicate that $C$. fluminea soft tissues can be a food resource to these species if they overcome the physical defenses represented by the hard shells.

It is well described in the literature that some ecosystems are capable to recover from severe invasions. Native predators can learn to adapt to use IAS and this process can occur over different time scales (from few years to decades; Carlsson et al., 2009); this is especially valid for successful IAS that become highly abundant. In fact, there are some examples of systems invaded by $C$. fluminea in which this process has been observed across different time scales. For example, in Ging Creek, USA, the Musk Turtles Sternotherus odoratus (Latreille, 1801) started to eat the Asian clam 40 years after the introduction; in this system, the turtles shifted toward a molluscivory diet and $C$. fluminea started to represent a large part of their diet (72\%) (Wilhem \& Plummer, 2012). Also, in Fairfield Reservoir, Texas, USA, fish predators contributed to a 29-fold reduction of $C$. fluminea abundance 20 years after its introduction and this situation had prevented the species to reach a high density (Robinson \& Wellborn, 1988). On the other hand, Oliva et al. (1981) reported predation of C. fluminea by the Spotted Pim Pimelodus maculatus (Lacépède, 

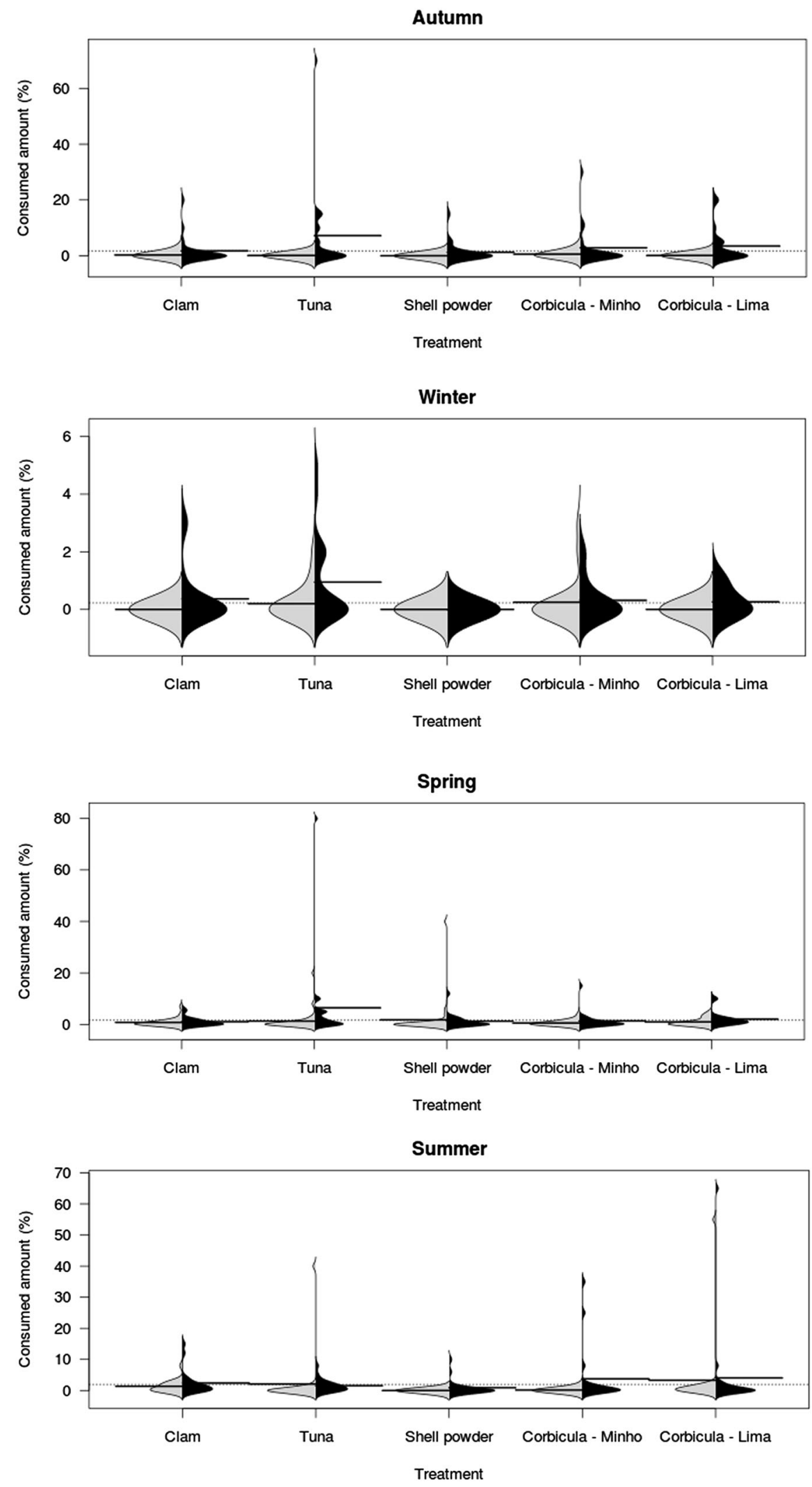
Fig. 3 Overall consumption of the five different treatments (Clam, Tuna, Shell powder, Corbicula Minho, and Corbicula Lima) in the laboratory assays. Different letters indicate significant differences between them (two-way PERMANOVA pairwise tests; $P<0.05$ )

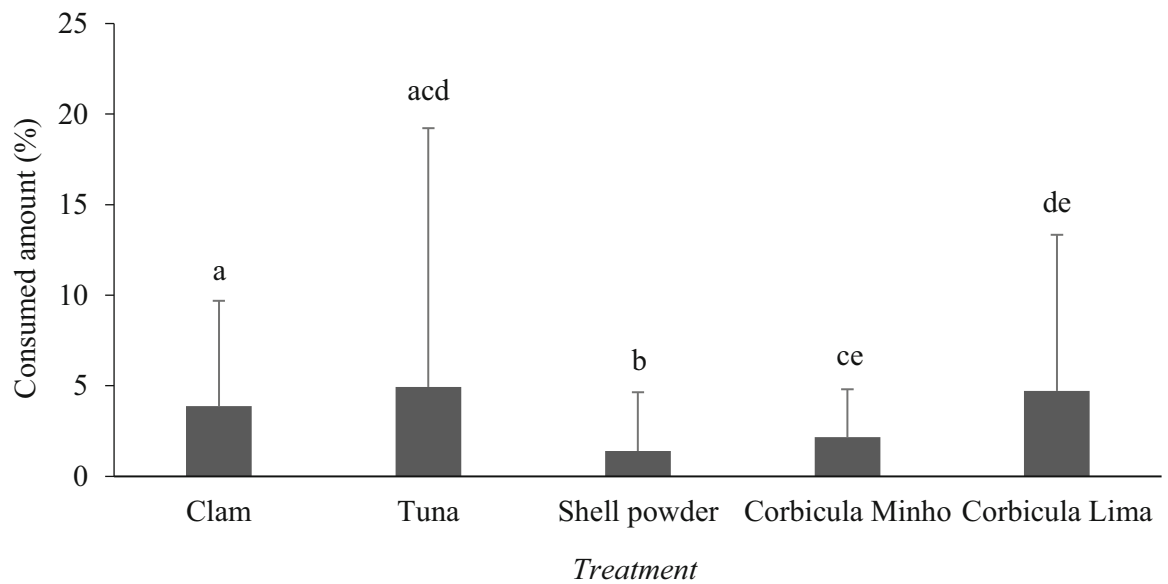

attractiveness to predators (especially in the field). This, among other possibilities, may be also the case for the successful invasion and high density reached by $C$. fluminea in the Minho River (Sousa et al., 2006, 2008c).

In the present study, a preference for the treatment Corbicula Lima was also observed compared to Corbicula Minho. Variation in species palatability is expected to occur between populations (Bolser \& Hay, 1996). For example, Bolser \& Hay (1996) observed between-population variation in palatability for the brown algae Dictyota within the same geographic region (North Carolina, USA). The palatability of a species is normally determined by their tissue features, such as structural characteristics (physical defenses), elemental characteristics (chemical defenses), and/or nutritional quality (Peck, 1993, 2001; Long et al., 2013). According to earlier studies, C. fluminea individuals from the Lima River are submitted to higher anthropogenic disturbance and nutrient concentrations compared to the individuals of the Minho River (Sousa et al., 2006). While in the Minho River, C. fluminea present a much higher density when compared to the Lima River, and probably is submitted to higher intraspecific competition. These conditions might limit the feeding activity of the species, and consequently contribute to the lower growth rates and undernourished conditions of the individuals present in Minho River (Sousa et al., 2006). Future detailed studies should be performed in order to better evaluate the nutritional conditions (or physical and chemical defenses) of the species in both rivers.

Furthermore, a similar preference for the treatments Tuna and Corbicula Lima was observed in the 
Fig. 4 Average consumption of Procambarus clarkii (a), Cyprinus carpio (b), Anguilla anguilla (c), and Lepomis gibbosus (d) of the five different treatments (Clam, Tuna, Shell powder, Corbicula Minho, and Corbicula Lima), during the day (gray color) and night (black color) periods. The overall food pellets' average consumption is represented by the dotted horizontal line

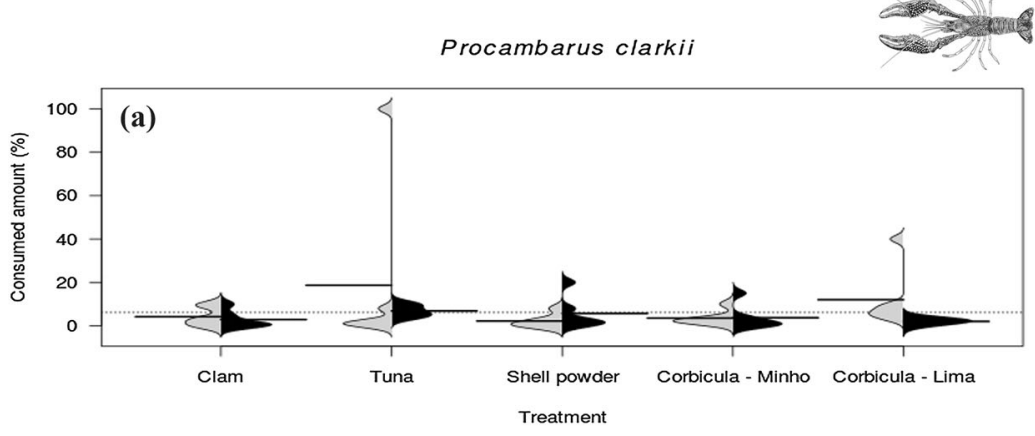

Cyprinus carpio

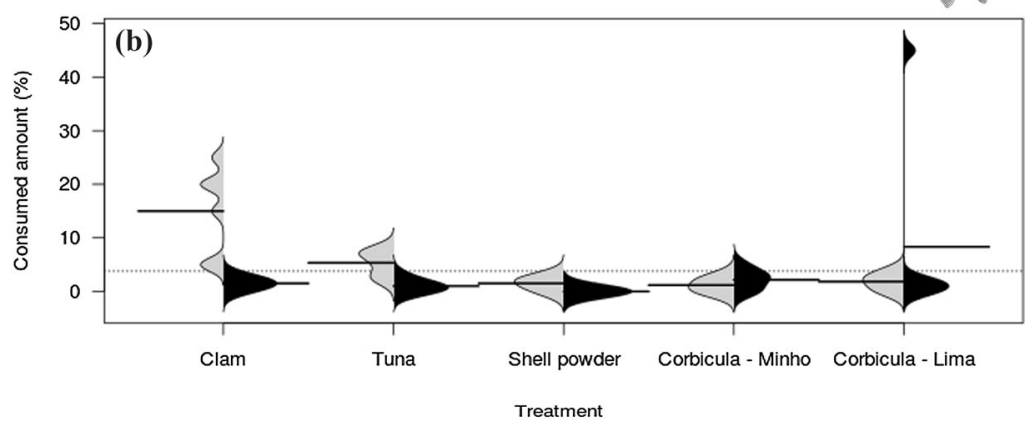

Anguilla anguilla
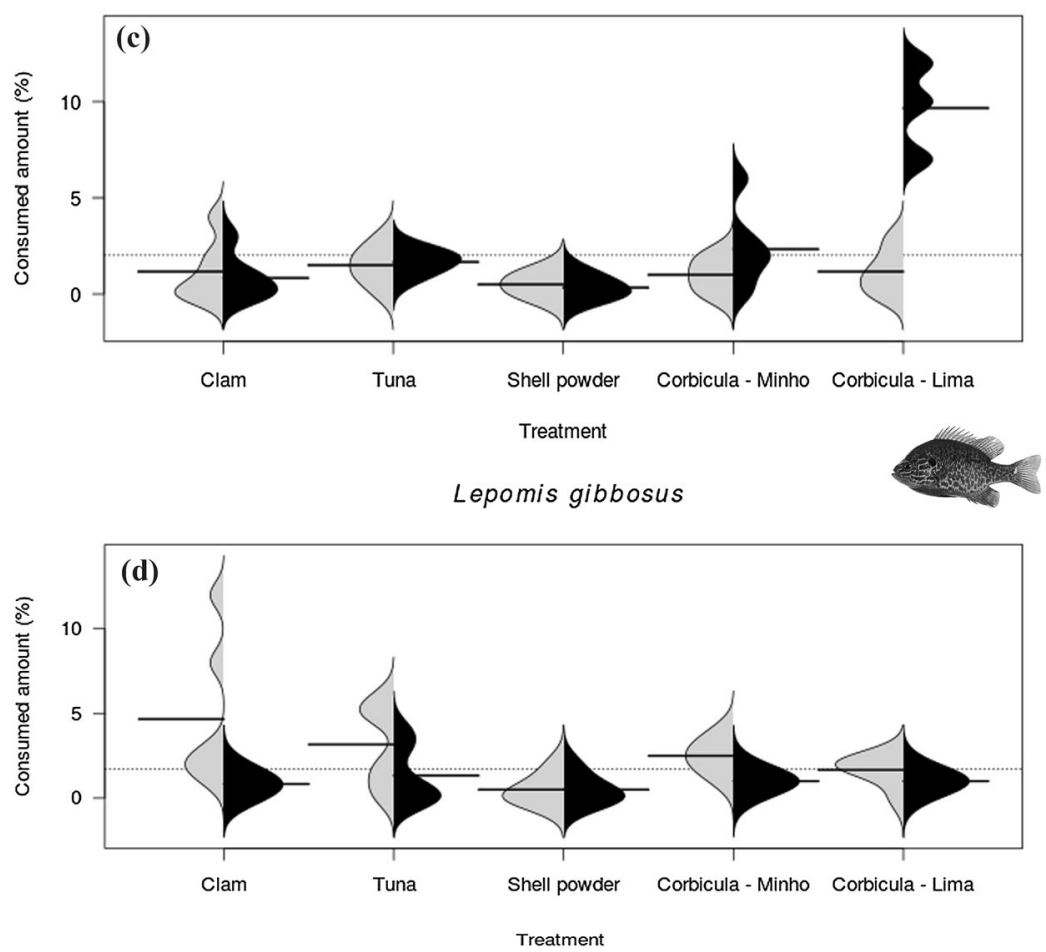
Table 2 Two-way PERMANOVA results (all species and individually) comparing the consumption of the treatments (Clam, Tuna, Shell powder, Corbicula Minho, Corbicula Lima) in the laboratory assays among day period (day and night)

$n s$ non-significant $P$ value

\begin{tabular}{llllll}
\hline Source & df & SS & MS & Pseudo-F & $P$ \\
\hline Treatment & 4 & 41.97 & 10.49 & 3.86 & $<0.001$ \\
Day period & 1 & 17.48 & 17.48 & 6.43 & $<0.001$ \\
Treatment $\times$ day period & 4 & 40.61 & 10.15 & 3.73 & $<0.001$ \\
Procambarus clarkii & & & & & \\
$\quad$ Treatment & 4 & 3.96 & 0.99 & 0.97 & $\mathrm{~ns}$ \\
Day period & 1 & 1.20 & 1.20 & 1.17 & $\mathrm{~ns}$ \\
$\quad$ Treatment $\times$ day period & 4 & 2.80 & 0.70 & 0.69 & $\mathrm{~ns}$ \\
Cyprinus carpio & & & & & \\
$\quad$ Treatment & 4 & 7.84 & 1.96 & 2.61 & $<0.05$ \\
$\quad$ Day period & 1 & 1.54 & 1.54 & 2.04 & $\mathrm{~ns}$ \\
$\quad$ Treatment $\times$ day period & 4 & 11.99 & 2.99 & 3.99 & $<0.01$ \\
Anguilla anguilla & & & & & \\
$\quad$ Treatment & 4 & 22.12 & 5.53 & 26.71 & $<0.001$ \\
$\quad$ Day period & 1 & 6.45 & 6.45 & 31.18 & $<0.001$ \\
$\quad$ Treatment $\times$ day period & 4 & 20.08 & 5.02 & 24.25 & $<0.001$ \\
Lepomis gibbosus & & & & & \\
$\quad$ Treatment & 4 & 8.05 & 2.01 & 2.72 & $<0.05$ \\
$\quad$ Day period & 1 & 8.29 & 8.29 & 11.21 & $<0.01$ \\
$\quad$ Treatment $\times$ day period & 4 & 5.72 & 1.43 & 1.94 & $\mathrm{~ns}$ \\
\hline
\end{tabular}

comparison of the field and laboratory assays. This result suggests that the experimental approach adopted was consistent and effective. Also, low consumption rates were noticed in the field assays during winter, possibly associated to the low water temperature that decreases the consumers metabolic rates (Huusko et al., 2007); this argument is particularly suitable since poikilothermic fish and crustacean species comprise most of the consumers in the study area. Differences in consumption concerning the period of the day were also noted. In the field, the highest consumption was observed during the night, while in the laboratory was during the day; further, the overall average consumption in the laboratory was higher than in the field. It seems that the species in the laboratory behave differently of what was expected and this could have contributed to some of the differences observed. Indeed, in the laboratory, the species were restricted to a limited area in which one individual per tank (with no competition or any other biotic interaction) was used and this situation may have changed the organism behavior and consequently lead to different results. Additionally, the laboratory results for the species $C$. carpio and A. anguilla, concerning the treatment Corbicula Lima, were relevant in the context of $C$. fluminea palatability.

\section{Conclusion}

The Asian clam is recognized as one of the most problematic IAS in aquatic ecosystems (Sousa et al., 2008d; Ilarri \& Sousa, 2012) and despite their ecological relevance few studies have investigated the use of the species as a food resource. This was the first attempt to evaluate $C$. fluminea soft tissues palatability and the results of the present study suggest that the treatments containing $C$. fluminea (i.e., Corbicula Minho and Corbicula Lima) had a low preference by the consumers (mainly in the field assays). However, it is important to mention that in laboratory some preference was observed regarding the species $C$. carpio and A. anguilla for the treatment Corbicula Lima, suggesting that $C$. fluminea soft tissues can be a food resource for some of these species if they overcome the physical defenses represented by their hard shells. Also, the palatability of the species can be different between populations.

Acknowledgments This study was conducted as part of the project FRESCHO: Multiple implications of invasive species on Freshwater Mussel coextinction processes, supported by FCT (contract: PTDC/AGRFOR/1627/2014). MI is supported by a Post-doc grant (SFRH/BPD/90088/2012) from the Portuguese Foundation for Science and Technology-FCT through POPH/ 
FSE funds. RS also acknowledge the support of the strategic programme UID/BIA/04050/2013 (POCI-01-0145-FEDER007569) funded by national funds through the FCT I.P and by the ERDF through the COMPETE2020_-Programa Operacional Competitividade e Internacionalização (POCI). Special thanks to Allan Souza and two anonymous reviewers for valuable suggestions, and to Luís Amorim for helping in the field assays.

\section{References}

Alofs, K. M. \& D. A. Jackson, 2014. Meta-analysis suggests biotic resistance in freshwater environments is driven by consumption rather than competition. Ecology 95: 3259-3270.

Anderson, M. J., 2001. A new method for non-parametric multivariate analysis of variance. Austral Ecology 26: 32-46.

Anderson, M. J., R. N. Gorley \& K. R. Clarke, 2008. PERMANOVA + for PRIMER: guide to software and statistical methods. Plymouth, PRIMER-E.

Araujo, R., D. Moreno \& M. A. Ramos, 1993. The Asiatic clam Corbicula fluminea (Müller, 1774) (Bivalvia: Corbiculidae) in Europe. American Malacological Bulletin 10: 39-49.

Bolser, R. C. \& M. E. Hay, 1996. Are tropical plants better defended? Palatability and defenses of temperate versus tropical seaweeds. Ecology 77(8): 2269-2286.

Bouchereau, J., C. Marques, P. Pereira, O. Guelorget, S. Lourié \& Y. Vergne, 2009. Feeding behaviour of Anguilla anguilla and trophic resources in the Ingril Lagoon (Mediterranean, France). Cahiers de Biologie Marine 50: 319-322.

Carlsson, N. O. L., O. Sarnelle \& D. L. Strayer, 2009. Native predators and exotic prey - an acquired taste? Frontiers in Ecology and the Environment 7(10): 525-532.

Carlsson, N. O. L., H. Bustamante, D. L. Strayer \& M. L. Pace, 2011. Biotic resistance on the increase: native predators structure invasive zebra mussel populations. Freshwater Biology 56: 1630-1637.

Colautti, R. I., A. Ricciardi, I. A. Grigorovich \& H. J. Maclsaac, 2004. Is invasion success explained by the enemy release hypothesis? Ecology Letters 7: 721-733.

Crespo, D., M. Dolbeth, S. Leston, R. Sousa \& M. A. Pardal, 2015. Distribution of Corbicula fluminea in the invaded range: a geographic approach with notes on species traits variability. Biological Invasions 17: 2087-2101.

Dorn, N. J. \& M. Hafsadi, 2016. Native crayfish consume more non-native than native apple snails. Biological Invasions 18: $159-167$.

Ehrenfeld, J. G., 2010. Ecosystem consequences of biological invasions. Annual Review of Ecology, Evolution, and Systematics 41: 59-80.

Epifanio, R. A., D. L. Martins, R. Villaça \& R. Gabriel, 1999. Chemical defenses against fish predation in three Brazilian octocorals: $11 \beta, 12 \beta$ epoxypukalide as a feeding deterrent in phyllogorgia dilatata. Journal of Chemical Ecology 25(10): 2255-2265.

Ford, S. D., 1996. Range extension by the oyster parasite Perkinsus marinus into northeastern United States: response to climate change? Journal of Shellfish Research 15: 45-56.

French, J. R. P. I. I. I., 1993. How well can fishes prey on zebra mussels in eastern North America? Fisheries 18: 13-19.

Gutiérrez, J. L., C. G. Jones \& R. Sousa, 2014. Toward an integrated ecosystem perspective of invasive species impacts. Acta Oecologica 54: 131-138.

Huusko, A., L. Greeberg, M. Stickler, T. Linnansaari, M. Nykänen, T. Vehanen, S. Koljonen, P. Louhi \& K. Alfredsen, 2007. Life in the ice lane: the winter ecology of streams Salmonids. River Research and Applications 23: 469-491.

Ibrahim, A. M., M. T. Khalil \& M. F. Mobarak, 1995. On the feeding behavior of the exotic crayfish Procambarus clarkii in Egypt and its prospects in the biocontrol of local vector snails. Journal of Union of Arab Biologists Cairo 4: 321-340.

Ilarri, M. \& R. Sousa, 2012. Corbicula fluminea Müller (Asian clam). In Francis, R. A. (ed.), A handbook of global freshwater invasive species. Earthscan, London: 173-183.

Ilarri, M. I., C. Antunes, L. Guilhermino \& R. Sousa, 2011. Massive mortality of the Asian clam Corbicula fluminea in a highly invaded area. Biological Invasions 13(2): 277-280.

Ilarri, M. I., A. T. Souza, C. Antunes, L. Guilhermino \& R. Sousa, 2014. Influence of the Asian clam Corbicula fluminea (Bivalvia: Corbiculidae) on estuarine epibenthic assemblages. Estuarine Coastal and Shelf Science 143: $12-19$.

Ilarri, M. I., A. T. Souza \& R. Sousa, 2015a. Contrasting decay rates of freshwater bivalves' shells: aquatic versus terrestrial habitats. Limnologica 51: 8-14.

Ilarri, M. I., A. T. Souza, V. Modesto \& R. Sousa, 2015b. Differences in the macrozoobenthic fauna colonizing empty bivalve shells before and after invasion by Corbicula fluminea. Marine and Freshwater Research 66(6): 549-558.

Ilhéu, M., J. M. Bernardo \& S. Fernandes, 2007. Predation of invasive crayfish on aquatic vertebrates: the effect of Procambarus clarkii on fish assemblages in Mediterranean temporary streams. Biological Invaders in Inland 29: 543-558.

Keane, R. M. \& M. J. Crawley, 2002. Exotic plant invasions and the enemy release hypothesis. Trends in Ecology and Evolution 17: 164-170.

Long, J. D., L. Porturas, E. Jones, C. Kwan \& G. C. Trussell, 2013. Seaweed traits linked to wave exposure determine predator avoidance. Marine Ecology Progress Series 62: $175-183$.

Lonsdale, W. M., 1999. Global patterns of plant invasions and the concept of invisibility. Ecology 80: 1522-1536.

Molloy, D., A. Karatayev, L. E. Burlakova, D. P. Kurandina \& F. Laruelle, 1997. Natural enemies of zebra mussels: predators, parasites, and ecological competitors. Reviews in Fisheries Science 5: 27-97.

Mota, M., R. Sousa, A. Bio, J. Araújo, C. Braga \& C. Antunes, 2014. Seasonal changes in fish assemblages in the River Minho tidal freshwater wetlands, NW of the Iberian Peninsula. Annales de Limnologie-International Journal of Limnology 50: 185-198.

Novais, A., A. Souza, M. Ilarri, C. Pascoal \& R. Sousa, 2015a. From water to land: how an invasive clam may function as 
a resource pulse to terrestrial invertebrates. Science of the Total Environment 538: 664-671.

Novais, A., A. T. Souza, M. Ilarri \& R. Sousa, 2015b. Facilitation in the low intertidal: effects of an invasive species on the structure of an estuarine macrozoobenthic assemblage. Marine Ecology Progress Series 522: 157-167.

Novais, A., A. Souza, M. Ilarri, C. Pascoal \& R. Sousa, 2016 a. Effects of the invasive clam Corbicula fluminea (Müller, 1774) on an estuarine microbial community. Science of the Total Environment 566-567: 1168-1175.

Novais, A., E. Dias \& R. Sousa, 2016b. Inter-and intraspecific variation of carbon and nitrogen stable isotope ratios in freshwater bivalves. Hydrobiologia 765(1): 149-158.

Oliva, A., C. A. Ubeda, I. E. Vignes \& A. Uriondo, 1981. Contribucíon al conocimento de la ecología alimentaria del bagre amarillo (Pimelodus maculatus Lacépède, 1803) del Río de la Plata (Pisces, Pimelodidae). Revista del Museo de Ciencias Naturales 1: 30-50.

Pawlik, J. R. \& W. Fenical, 1992. Chemical defense of Pterogorgia anceps, a Caribbean gorgonian coral. Marine Ecology Progress Series 87: 183-188.

Peck, L. S., 1993. The tissues of articulate brachiopods and their value to predators. Philosophical transactions of the royal society B 339: 17-32.

Peck, L. S., 2001. Ecology of articulated brachiopods. In Carlson, S. J. \& M. R. Sandy (eds), Brachiopods ancient and modern: a tribute to G. Arthur Cooper, 7. The Paleontological Society, New Haven: 171-183.

Pereira, L. J., S. Pinho, A. Ré, P. A. Costa, R. Costa, F. Gonçalves \& B. B. Castro, 2016. Biological control of the invasive Asian clam, Corbicula fluminea: can predators tame the beast? Hydrobiologia 779: 209-226.

Robinson, J. V. \& G. A. Wellborn, 1988. Ecological resistance to the invasion of a freshwater clam, Corbicula fluminea: fish predation effects. Oecologia 77: 445-452.

Simberloff, D., J. L. Martin, P. Genovesi, V. Maris, D. Wardle, J. Aronson, F. Courchamp, B. Galil, E. Garcia-Berthou, M. Pascal, P. Pyšek, R. Sousa, E. Tabacchi \& M. Vilà, 2013. Impacts of biological invasions: what's what and the way forward. Trends in Ecology and Evolution 28: 58-66.

Sousa, R., L. Guilhermino \& C. Antunes, 2005. Molluscan fauna in the freshwater tidal area of the River Minho estuary, NW of Iberian Peninsula. Annales de Limnologi-International Journal of Limnology 41: 141-147.

Sousa, R., C. Antunes \& L. Guilhermino, 2006. Factors influencing the occurrence and distribution of Corbicula fluminea (Müller, 1774) in the River Lima estuary. Annales de Limnologie-International Journal of Limnology 42: 165-171.
Sousa, R., A. J. A. Nogueira, M. B. Gaspar, C. Antunes \& L. Guilhermino, 2008a. Growth and extremely high production of the non-indigenous invasive species Corbicula fluminea (Müller, 1774): possible implications for ecosystem functioning. Estuarine, Coastal and Shelf Science 80: 289-295.

Sousa, R., S. Dias, V. Freitas \& C. Antunes, 2008b. Subtidal macrozoobenthic assemblages along the River Minho estuarine gradient (north-west Iberian Peninsula). Aquatic Conservation: Marine and Freshwater Ecosystems 18: 1063-1077.

Sousa, R., M. Rufino, M. Gaspar, C. Antunes \& L. Guilhermino, 2008c. Abiotic impacts on spatial and temporal distribution of Corbicula fluminea (Müller, 1774) in the River Minho estuary, Portugal. Aquatic Conservation: Marine and Freshwater Ecosystems 18: 98-110.

Sousa, R., C. Antunes \& L. Guilhermino, 2008d. Ecology of the invasive Asian clam Corbicula fluminea (Müller, 1774) in aquatic ecosystems: an overview. Annales LimnologiaInternational Journal of Limnology 44: 85-94.

Sousa, R., P. Morais, E. Dias \& C. Antunes, 2011a. Biological invasions and ecosystem functioning: time to merge. Biological Invasions 13: 1055-1058.

Sousa, R., M. Ilarri, A. T. Souza, C. Antunes \& L. Guilhermino, 2011b. Rapid decline of the greater European peaclam at the periphery of its distribution. Annales Limnologie-International Journal of Limnology 47: 211-219.

Sousa, R., F. Freitas, A. J. A. Nogueira, M. Mota \& C. Antunes, 2013. Invasive dynamics of the crayfish Procambarus clarkii (Girard, 1852) at the international section of the River Minho (NW of the Iberian Peninsula). Aquatic Conservation: Marine and Freshwater Ecosystems 23: 656-666.

Strayer, D. L., 2012. Eight questions about invasions and ecosystem functioning. Ecology Letters 15: 1199-1210.

Tucker, J. K., F. A. Cronin, D. W. Soergel \& C. H. Theiling, 1996. Predation on zebra mussels (Dreissena polymorpha) by common carp (Cyprinus carpio). Journal of Freshwater Ecology 11: 363-372.

Vilà, M., C. Basnou, P. Pyšek, M. Josefsson, P. Genovesi, S. Gollasch, W. Nentwig, S. Olenin, A. Roques, D. Roy, P. E. Hulme \& DAISIE partners, 2010. How well do we understand the impacts of alien species on ecosystem services? A pan-European cross-taxa assessment. Frontiers in Ecology and the Environment 8: 135-144.

Wilhem, C. \& M. Plummer, 2012. Diet of radiotracked musk turtles, Sternotherus odoratus, in a small urban stream. Herpetological Conservation and Biology 7: 258-264. 